\title{
Chapter 2 \\ Synergies and Conflicts Between Water \\ Framework Directive and Natura 2000: \\ Legal Requirements, Technical Guidance and Experiences from Practice
}

\author{
Georg A. Janauer, Juliane Albrecht and Lars Stratmann
}

\begin{abstract}
The EU water framework directive (WFD) is intensively connected with other European legal regulations and supporting documents. This close interrelationship calls for deeper considerations when WFD is implemented in locations of high conservation value, e.g. Natura 2000 sites. A comprehensive, but specific comparison of the goals of WFD with the aims of habitats directive (HD) and birds directive (BD) provides a sensitive overview on their peculiarities, with an outlook on potential synergies and conflicts. The sometimes complex guidance for solving complicated situations in the practical application of these differing legal provisions is also described. The representation of requirements for Natura 2000 sites as part of river basin management plans, and related up-to-date experience are given special attention. Finally recommendations and conclusions provide the reader with a complete view of this challenging chapter in European Policy. In the end, considerably more synergies than conflicts are identified between the objectives of WFD, HD and BD. Whenever conflicts should arise these directives prevent derogating from their requirements by cross-references. Therefore, firm and timely coordination between water and nature conservation authorities is necessary.
\end{abstract}

Keywords Water framework directive - Habitats directive - Birds directive • River basin management plan • Natura 2000 sites - Implementation

\footnotetext{
G.A. Janauer $(\bowtie)$

Department of Limnology and Biological Oceanography, University of Vienna, Althanstr. 14, 1090 Vienna, Austria

e-mail: georg.janauer@univie.ac.at

J. Albrecht · L. Stratmann

Leibniz Institute of Ecological Urban and Regional Development, Weberplatz 1, 01217 Dresden, Germany

(C) The Author(s) 2015

S. Ignar and M. Grygoruk (eds.), Wetlands and Water Framework Directive,

GeoPlanet: Earth and Planetary Sciences, DOI 10.1007/978-3-319-13764-3_2
} 


\subsection{Introduction}

The water framework directive (Directive 2000/60/EC, WFD) is not a stand-alone document of European legal regulation, but is in many ways integrated into a spider web of relationships with other directives and documents of European policy. This contribution aims at highlighting some of the more fundamental connections between relevant EU documents covering a wide scope that considers various aspects of water related issues, cross-linking water management with nature protection and conservation needs.

Due to its ecological approach, the WFD shows numerous connections with nature conservation. The WFD strives primarily for an improvement on the habitat quality and the diversity of species in surface waters by the criteria of good ecological and chemical status and corresponding measures in the programmes of measures (Art. 1 a); Art. $2 \mathrm{~N}^{\circ}$. 18; Art. 4 para. 1 a) ii) and iii); Annex $5 \mathrm{~N}^{\circ} .1 .2$ table 1.2 WFD), among other things provides protection against impairments for wetlands directly depending on the aquatic ecosystems (Art. 1 a) WFD) and refers to the management objectives for Natura 2000 sites (Annex IV part A and Annex V $\mathrm{N}^{\circ}$. 1.3.5 WFD). The interplay of WFD and Natura 2000 directives, i.e., the HD and the $\mathrm{BD}$, is of high practical relevance, because measures according to WFD regularly take place within Natura 2000 sites.

Particularly interesting from an environment protection point of view are the special areas of conservation (SAC) and the special protection areas (SPA) that were to be allocated by the Member States as a coherent European ecological network according to the HD and the BD. Within the relevant sanctuaries all bird species listed in Annex I of the BD and special protection areas for commonly visiting migratory birds are protected by Article $4 \mathrm{BD}$. The protection out of Article $4 \mathrm{HD}$ relates to either habitat types that are of collective conservation interest (Annex I) or to wild species deserving protection in accordance with Annex II and IV of the directive (Unnerstall 2003, p. 670; Louis 2000, p. 83 et seq.).

Main aims of the following contribution are to highlight potential synergies and conflicts of WFD implementation in Natura 2000 sites, to pass on some experience on this topic as well as to give recommendations for the coordinated implementation of the legal requirements. The contribution is subdivided into four sections. In Sect. 2.2, the goals of WFD and Natura 2000 legislation are compared, main interrelations highlighted and synergies as well as conflicts are shown. Section 2.3 gives an overview on legal provisions and guidance documents on the European level relating the question how to deal with synergies and conflicts between WFD and Natura 2000 in practice. In Sect. 2.4, the implementation of WFD in Natura 2000 sites as part of river basin management plans is discussed, up-to-date experiences are shared and recommendations given. Finally conclusions are drawn (Sect. 2.5). 


\subsection{Comparison of Goals of WFD and Natura 2000: Analogue and Antagonism}

\subsubsection{Goals of WFD, HD and BD}

Goals of WFD are, when focused on the two most stringent ones, preventing further deterioration of aquatic ecosystems and associated wetlands as well as terrestrial environments and the enhancement of their ecological quality where a good, or better, ecological status is not reached at present (Art. 4 WFD).

Setting the reference conditions in conformity with the natural or near natural state of rivers and lakes, as regards surface waters, requests "re-regulation" of a great number of river reaches throughout all EU Member States. As a consequence, many activities covered by current river basin management plans are centred on river re-naturalisation. This includes not only the river course, which is often far from natural state due to regulation measures (e.g. straightening the course, cutting oxbows), but relates also to river bank enforcement (e.g. rip-rap) or groundsills and any other construction type by which river gradient needs to be attenuated to stop river bed incision processes. The other aspect of 'hydro-morphological' impacts relates to non-natural flow conditions, e.g. caused by diversion power plants, which reduce the discharge in affected river reaches to levels below 'ecological flow' (Gopal 2013), the amount of water needed to support all aquatic life characteristic for such a river part.

Ecological parameters are not the only aspect in WFD implementation, as accompanying environmental conditions supporting 'good ecology' must be met, too. For achieving a good surface water status, a chemical status of at least 'good', requiring the compliance with certain environmental quality standards (for details see Art. $2 \mathrm{~N}^{\circ} .24$ WFD), is also obligatory (Art. $2 \mathrm{~N}^{\circ} .18$ WFD).

Another aspect of WFD goals is the relevance given to groundwater, which is a valuable source for surface waters and associated terrestrial ecosystems (Art. 4 (1) b) WFD, Art. $2 \mathrm{~N}^{\circ} .27$ WFD), but by far one of the most important drinking water resources for humankind. Regarding groundwater, its availability, its quantity (Art. $2 \mathrm{~N}^{\circ} .26$ and 28, and table 2.1.2 Annex V), and its chemical status (Art. $2 \mathrm{~N}^{\circ} .25$ ) are to be observed.

In combination with the intrinsic concept of integrating the river basin into all considerations on resulting surface and ground water quality this results in a much wider scope of interpretation of water quality than any other water quality regulation so far developed. However, this implies that land cover and land use aspects as determinants of water quality meet a level of importance which will result in far reaching influence on future general policies regarding the landscape in total.

Goals of the habitats directive 1992 (HD) are, in a focused view 'ensuring biodiversity through the conservation of natural habitats and of wild fauna and flora' in the EU Member States. To reach these goals a 'favourable conservation status' of habitats and related species shall be maintained in the context of 'long-term survival' (Art. 1 (e) HD). This implies that ecologically valuable habitats - their value based 
on the composition of species and their physical setting - shall be protected and maintained if favourable conservation status is already accomplished, or measures shall be taken to reach this status in case the present condition is not in compliance with that goal.

Art. 2 HD proclaims in general terms that all measures taken by Member States pursuant to the directive 'shall be designed to maintain or restore, at favourable conservation status, natural habitats and species of wild fauna and flora of community interest'. According to the Directive, the status of a habitat qualifies as 'favourable' when, among other things, its range is 'stable or increasing' and the 'structure and functions which are necessary for its long-term maintenance exist and are likely to continue to exist for the foreseeable future'. The conservation status of a species is deemed favourable when, inter alia, the species 'is maintaining itself on a long-term basis as a viable component of its natural habitats' and 'there is, and will probably continue to be, a sufficiently large habitat to maintain its populations on a long-term basis'.

The BD (1979) in its present 'codified' version of 2009 (Directive 2009, based on the amended version of Council Directive 79/409/EEC of 2 April 1979) relates to the conservation of all species of naturally occurring birds in the wild state in the territory of the European Member States. It covers the protection, management and control of these species and lays down rules for their exploitation. The directive applies to birds, their eggs, nests and habitats (Art. 1 BD). Member States shall take the requisite measures to maintain the population of the bird species at a level which corresponds in particular to ecological, scientific and cultural requirements, while taking account of economic and recreational requirements, or to adapt the population of these species to that level (Art. 2 BD). Art. 1 and 2 BD do not contain the words 'favourable conservation status', but are generally understood to imply this purpose for wild birds (Trouwborst 2011, p. 70 et seq.).

A coherent European ecological network of SAC shall be set up under the title of "Natura 2000", composed of sites hosting the natural habitat types listed in Annex I and habitats of the species listed in Annex II (Art. 3 HD). These special areas of conservation protected by the HD include, inter alia, aquatic habitats such as stagnant and flowing water bodies and submerged vegetation, which are in the focus of the WFD, too (Friedrich 2003, p. 39). As designated in Art. 3 HD, the Natura 2000 network includes also the special protection areas classified by the Member States pursuant to the BD. Insofar, the bird's protection measures are integrated to the system that has been created by the HD. The coherent Natura 2000 designated areas must be secured by appropriate conservation measures. Relevant species and their habitats should be effectively protected from considerable harm and should maintain a favourable degree of conservation.

Both the BD and the HD are, at least in part, fundamentally connected with the WFD. The BD lists in its Article 4 that 'Member States shall pay particular attention to the protection of wetlands', including 'wetlands of international importance', but explicitly not addressing these latter types exclusively. Yet, as a large group of wild birds depends on wetlands, this Directive is also closely connected to the intrinsic topic of the Ramsar Convention of 1975 ('Convention on Wetlands of International 
Importance 1971 '). This convention highlights the importance of wetlands in a very broad sense. Important wetland types are 'lakes and pools; rivers and streams; bogs, marshes and swamps; and coastal lagoons', as listed in the web reference (see footnote 1). Yet, one basic feature of the BD is it being exclusively and solitarily focused on a single group of organisms which is just one group of many protected by the HD. This fact has shown in integrated planning teams that enforcing the interests of the avifauna above that of other groups of organisms becomes evident. Certainly a balanced consideration of the interest of all organisms of ecological value should be more desirable.

Regarding the HD this directive has a much wider scope than the BD as many habitat types of the HD relate to aquatic or wetland vegetation units and associated faunal elements, which depend either on surface water connection or groundwater supply. Yet not all the sites to which certain habitat types relate in principle are necessarily part of protected areas coherent with the Natura 2000 concept that forms the elementary backbone of the HD, as it assigns 'special areas of conservation' (Art. 3 HD).

Wetlands depending on surface waters or groundwater are considered an intrinsic part of the WFD, and therefore both the $\mathrm{BD}$, with respect to avian life depending on wetlands, and the HD, which lists many types of wetland related vegetation types, have to be respected when developing management strategies to reach good ecological (and chemical) status of surface waters and good groundwater bodies. Yet, in its essence the WFD is a directive for water management in a very wide sense, but not a focal directive on nature protection. Therefore, the aims of the WFD are not in all cases and locations completely congruent with the exclusively ecological and/or conservational focus of - in a more general view-the $\mathrm{HD}$, and equally not the BD.

\subsubsection{Potential Synergies Between Goals of WFD and Natura 2000}

After the WFD came into force, uncertainties with regard to the interaction of nature conservation and water management existed (Köhler 2003, p. 106; Schönauer 2007, p. 87). For a better use of synergies between WFD and Natura 2000 within the next planning phases of River Basin Management Plans (RMBP) and to avoid conflicts, it seemed appropriate, to assess potential synergies and conflicts between the goals of WFD and Natura 2000. In this and the following section these potentials are discussed, as were identified within the scope of an evaluation of both directives and all RBMPs in Germany.

The ecosystem approach of the WFD can contribute to the achievement of conservation objectives when reaching the good ecological status of surface waters which has positive effects on their function as habitat for animals and plants in relation to the HD (Kastens 2003, p. 292). 
The exchange of populations as well as the development of a habitat network are aims of the Natura 2000 concept as well as of the WFD ('river continuity'). With respect to the conservation areas Annex IV Number 1 lit. v) WFD explicitly refers to the Natura 2000 sites. The requirements of the WFD refer to the longitudinal and the lateral continuity of rivers. In accordance with the environmental conditions of good ecological status, unhampered migration of aquatic species and the transportation of sediments should be possible both from the river head to the water mouth and from the river to the wetlands attached to it. In connection with this situation, the importance of rivers and wetlands for the functioning of the habitat network has to be stressed. These linear elements are important for re-connecting isolated habitats (Busse 2009) acting as corridors for an active and passive, longitudinal and lateral spreading of species in general (Brunken and Meyer 2005, p. 111).

The restoration of dynamic floodplains and their drift zone is a further objective which contributes to both directives - the development of the Natura 2000 network as well as to achieve a good ecological condition for which the presence of fish is an important indicator. Alluvial forests (as mentioned in Annex I WFD) require pioneer sites for their establishment and Annex II of the habitats directive contains predominantly rheophylic fish species whose sustainable protection is only possible in dynamic water bodies (Korn et al. 2005, p. 77; Wendler and Albrecht 2012, p. 42).

Examples for the synergetic effects between the continuing implementation of the WFD and wildlife conservation measures in Germany can be found in reintroduction projects of the salmon (Salmo salar) (e.g. migratory fish project of the Ministry for Climate Protection, Environment, Agriculture, Nature Conservation and Consumer Protection of the German State of North Rhine-Westphalia), the beaver (Castor fiber) (e.g. projects in the Eifel region and at the lower Rhine) and wildlife conservation measures for water-dependent species such as freshwater pearl mussels (Margaritifera margaritifera) (q.v. Becker and Rebsch 2006). In the Rhine River especially the construction of the fish pass at the Iffezheim hydroelectric power plant supports the migration of salmon and other rheophylic fish species very efficiently and provides a paramount example for rehabilitating river continuity.

All in all considerably more synergies than conflicts can be identified between the objectives of the WFD and those of the environmental conservation (cf. Wendler and Albrecht 2012, p. 33 et seq. and p. 41). This is inter alia noticeable in the instruments' approach as they focus both on the ecosystem, also in the development of rivers, brooks, alluvial plains and shores as well as in the expansion of the habitat network and the protection and further development of Natura 2000 sites. Particularly for the indigenous species and habitats, synergies are to be expected. Furthermore, the objectives of the WFD and the Natura 2000 directives serve the purposes of preventive flood protection, climate change mitigation and climate adaptation. These synergies can take effect because a large number of rivers and parts of the respective valleys are protected through the HD as special areas of conservation and therefore are subjected to the overlapping spatial scope of both directives (Albrecht et al. 2012; Hofmann and Schmidt 2012, p. 195). 


\subsubsection{Potential Conflicts Between Goals of WFD and Natura 2000}

However, the objectives of the WFD on the one hand and the Habitats and birds directives on the other hand may also evoke opposing effects, especially if water dependent Natura 2000 sites with secondary biotopes or species of cultural landscapes are concerned (Fuchs et al. 2010, p. 113 et seq.; Wirth et al. 2000 seq): The WFD concept of reference conditions is based on existing natural or near-natural river reaches. If such examples are missing at present, historical informationwhere available — or modelling approaches can be applied to reconstruct historical conditions. If neither of these ways can be followed successfully, expert judgement is requested to define reference conditions. The requirements of HD relate to the present and not to any historical conditions of the relevant habitats. This difference can lead to conflict of interest.

In aquatic systems, especially those represented by regulated rivers and their floodplain water bodies, e.g., cut-off side channels and oxbows, WFD calls for reestablishing the historical situation, which was characterised by permanent interconnection of most floodplain waters. Therefore, still water environments, which is the character of former river bends or loops turned into oxbows by regulation measures, are not the near natural condition defined for high ecological status, and do certainly not conform with the definition of 'good ecological status', demanding that: "The values of the biological quality elements for the surface water body type show low levels of distortion resulting from human activity, but deviate only slightly from those normally associated with the surface water body type under undisturbed conditions" (Annex V No. 1.2 table 1.2 WFD). The present condition of cut-off meanders and river channels deviates more than just 'slightly' from their former structure and hydrology, and 'good ecological status' defined by WFD cannot be appointed to these aquatic habitats. In such cases, the conservational values regarding the $\mathrm{HD}$ (and sometimes the $\mathrm{BD}$ ) compete against a full reclamation of river dynamics when strictly implementing WFD aims.

On the other hand, recent studies in the Austrian 'Danube National Park' (by appointment of IUCN) revealed two diverging situations. Floodplain waters characterised by high connectivity with the main river channel were either free of aquatic plant growth or showed very low diversity and abundance of these plants. In contrast, water bodies with moderate to low connectivity with the main river channel are inhabited by highly valuable aquatic vegetation and its associated fauna, from invertebrate level to amphibians, birds and mammals, which developed since river regulation was finalised in the mid-1870s.

In the first type of floodplain waters the situation of aquatic plants is comparable with that of main river courses and active side channels. WFD would require little or no changes in morphology and/or connectivity conditions, whereas the conservation status may well comply with a 'favourable' situation.

In the second type of floodplain waters, which were active side channels in preregulation time, WFD would require action towards considerably intensifying 
connectivity with the main river stem, i.e. towards a near-natural status. This would lead to an extreme decrease or even the terminal loss of the present aquatic vegetation and its associated fauna, but good or high ecological status in full accordance with running water conditions would be reached. On the other hand, our study showed that the present conservation status can be classified as favourable in the majority of that type of water bodies. This condition shall not be deteriorated by any human intervention according to HD. Yet, the enhancement of the ecological status à la WFD towards pre-regulation conditions with high connectivity with the main river channel would terminate the present diversity and abundance of aquatic flora and fauna. This would be a clear opposite to the goals of HD.

The most prominent EU document focusing on potential conflicts between WFD and HD/BD comprises a multitude of aspects related to this important topic (EC DG-Env 2011). Yet, practical application is in no way easily achieved, as the WFD aim of good status requires biological quality elements to 'deviate only slightly from those normally associated with ... undisturbed conditions' (Annex V N 1.2 table 1.2 WFD). Concerning water bodies in river floodplains this means to implement permanently running water conditions again. Yet, as already stated above, numerous examples exist where 'regulation-artefacts' like oxbows have developed over a long time into habitats of highest conservational value, regarding their aquatic flora and fauna. In such cases, conflicting goals must be dealt with.

\subsection{Implementation of the WFD in Natura 2000 Sites: Legal Provisions and Guidance of the European Commission}

\subsubsection{Legal Requirements for Implementing the Environmental Objectives in Natura 2000 Sites}

After having detected the overlap between the objectives of the WFD and Natura 2000 as well as potential synergies and conflicts in Sect. 2.2, it needs defining which legal requirements exist for the coordinated implementation of the WFD in Natura 2000 sites.

First of all it has to be stated that the objectives of Art. 4 WFD apply to surface water bodies or groundwater, i.e. elements of precisely defined spatial extent (e.g. lakes, reservoirs, streams, rivers, canals, aquifers or part of them; (Art. $2 \mathrm{~N}^{\circ} .10$ and 12 WFD). Natura 2000 sites are only affected by the WFD if they are part of such water bodies or can be qualified as ground water dependent ecosystems. Regarding Natura 2000 sites in floodplains the WFD is unclear to which extent they are part of the surface water body. In a wide interpretation, floodplains may be considered as part of a surface water body (normally a river) as far as they are functionally connected (EC 2003a, p. 14).

Nevertheless, the interdependencies between water bodies and flood plains call at least for protecting floodplains indirectly to achieve the good ecological status of 
surface water: Floodplains are important as a habitat for fishes like eel or pike, for instance. Their abundance may decrease significantly in the absence of natural flood dynamics (Krug and Ehlert 2003, p. 56; Schäfer 2004, p. 9). Therefore, recreation and restoration of wetland areas are important measures which have to be taken to achieve the good ecological water status (cf. Annex VI part B (vii) WFD). However, species living outside water bodies like amphibians or 'water-bound' mammals (e.g. beavers) are not in the focus of the WFD.

If the objectives of the WFD are applicable in Natura 2000 sites, Art. 4 para. 1 c) WFD regulates that Member States shall achieve compliance with any standards and objectives of the WFD at the latest by 2015, unless otherwise specified in the Community legislation under which the individual protected areas have been established. Where more than one of the objectives under Art. 4 para. 1 WFD relates to a given body of water, "the most stringent shall apply" (Art. 4 para. 2 WFD). This regulation aims to ensure that eventually more strict regulations of nature conservation law are not weakened by the WFD.

The legal situation is different if the objectives of the WFD ("good water status") and Natura 2000 law ("favourable conservation status") are in conflict. For this case, the directives do not regulate any general priority of the objectives of the WFD or of Natura 2000 law (Fuchs et al. 2010, p. 100 et seq.; Möckel 2007, p. 606 et seq.). However, the directives provide instruments how to handle conflicts in the individual case. The preconditions of these instruments are introduced in the following section.

The objectives of the WFD and Natura 2000 may be in conflict, for instance, if the removal of barriers, such as dikes and dams, is necessary to restore the original (hydromorphological) status of the water body as it is required by the good ecological status (Art. 4 para. 1 WFD). This may cause negative impacts on the conservation status of Natura 2000 sites, because, for example, secondary biotopes which are protected by the HD may have developed alongside artificially retained rivers. If the retaining structures are removed to restore river continuity with the aim to improve ecological water status, this may have negative impacts on the conservation status of the protected Natura 2000 site.

The legal instrument to solve such conflicts is the HD Assessment (Art. 6 para. 3 and 4 HD) (Fuchs et al. 2010, p. 107 et seq.). As designated in Art. 6 para. 3 HD any project not directly connected with or necessary to the management of the Natura 2000 site but likely to have a significant effect thereon shall be subject to appropriate assessment of its implications for the site in view of the site's conservation objectives. The above-mentioned construction measures will regularly be qualified as projects in the sense of Art. 6 para. 3 WFD. In spite of a negative assessment of the implications for the site and in the absence of alternative solutions, such a project may be approved, if it must nevertheless be carried out "for imperative reasons of overriding public interest". The achievement of the objectives of Art. 4 WFD may justify an overriding interest and can even be allowed if the concerned site hosts a priority natural habitat type and/or a priority species, as it may have beneficial consequences of primary importance for the environment (cf. Art. 6 para. 4 sent. 3 HD). However, the Member State shall take all compensatory 
measures necessary to ensure that the overall coherence of Natura 2000 is protected and shall inform the Commission of the compensatory measures adopted (Art. 6 para. 4 sent. 1 and $2 \mathrm{HD}$ ).

\subsubsection{Exemptions from the Good Water Status}

If, vice versa, the prerequisites of Art. 6 para. $4 \mathrm{HD}$ are not fulfilled, e.g. because there is no overriding public interest for deteriorating the Natura 2000 site to achieve the good water status, this may imply the omission of necessary river improvement measures for the achievement of the good (ecological) water status. The resulting failure to reach good water status may be justified by the deviating objective of the good ecological potential in accordance with Art. 4 para. $1 \mathrm{c}$ ) and para. 3 WFD or by exemptions in accordance with Art. 4 para. 4 to 7 WFD.

The achievement of the good ecological potential instead of the good ecological status (cf. Art. 4 para. 1 c) WFD) might be justified if the concerned water body could be classified as heavily modified or artificial water body (for natural water bodies the objective of the ecological potential is not applicable). The good ecological potential is achieved if the values of the relevant biological quality elements of the river, for instance, reflect, as far as possible, those associated with the closest comparable surface water body type, given the physical conditions which result from the artificial or heavily modified characteristics of the water body (1.2.5. Annex V WFD). The classification as heavily modified or artificial is possible if the changes to the hydromorphological characteristics of the concerned water body being necessary for achieving the good ecological status would have significant adverse effects on the wider environment (cf. Art. 4 para. 3 a) (i) WFD), which may include also the deterioration of the ecological status of Natura 2000 sites. However, the Member States have to substantiate that the beneficial objectives for nature conservation served by the artificial or modified characteristics of the water body cannot, for reasons of technical feasibility or disproportionate costs, reasonably be achieved by other means, which are a significantly better environmental option (Art. 4 para. $3 \mathrm{~b}$ ) WFD). The designation as artificial or heavily modified and the reasons for it shall be specifically mentioned in the river basin management plans required under Art. 13 WFD and reviewed every 6 years.

If the omission of necessary hydromorphological restoration measures due to the protection of Natura 2000 sites impedes the achievement of the good water status in other water bodies than those which have been classified as heavily modified or artificial water bodies, this failure might also be justified by the exemptions designated in Art. 4 para. 4 and 5 WFD. Insofar, Art. 4 para. 4 WFD allowing extending the deadline for achieving the good status (i.e. 2015) under some preconditions by a maximum of 12 years seems to be less relevant, as the Natura 2000 sites have to be protected permanently, not only until 2027. In contrast, Art. 4 para. 5 WFD gives the opportunity to achieve less stringent environmental objectives beyond 2027 when they are affected by human activities, or their natural condition is such way that the achievement of these objectives would be infeasible or disproportionately expensive. 
It can be argued that the achievement of the good ecological status of a water body is infeasible, if it requires construction works in the river bed or in the flood plains which would destroy or deteriorate the conservation status of a Natura 2000 site. However, in such cases the Member States have to ensure that the targeted environmental needs (i.e. the maintenance of the Natura 2000 site) cannot be achieved by other means, which are a significantly better environmental option. Furthermore, the least possible changes to the water status have to be achieved, no further deterioration must occur in the status of the affected water body and the establishment of less stringent environmental objectives, and the reasons for it, have to be specifically mentioned in the river basin management plan and those objectives have to be reviewed every 6 years (Art. 4 para. 5 WFD).

To sum up it can be stated that both the HD and the WFD contain appropriate legal instruments and sufficient discretionary leeway to find environmentally sound decisions in the individual case, considering both the objectives of the WFD and Natura 2000. Water and nature conservation authorities should cooperate in elaborating these decisions and should justify them carefully.

\subsubsection{Guidance from the European Commission}

The problem of how to implement the objectives of the WFD in Natura 2000 sites also drew the attention of the European Commission (DG Environment) and guidance is provided through some documents. First notes for an integrated implementation of the goals of Natura 2000 and WFD were formulated already in the CIS guidance document $N^{\circ} 12$ (EC 2003b). Based on the first experiences with synergies and conflicts within the first planning phase, open questions were taken up and more detailed advice for the following planning phases were given (EC DG-Env 2010a, b, 2011).

Except for the more general reference to the two conservation-oriented Directives there is no direct link to Natura 2000 sites in WFD Annex VI, and of how to deal in specific situations. It was realised that the ecological conditions of wetlands across Europe are so highly diverse that a management principle of 'one size fits all' does not consider specifics of national importance, and e.g. the consideration of environmental flow was to be worked out as a CIS Guidance document $\mathrm{N}^{\circ} 12$ (EC 2003b, specifically Chap. 5). As a first step, this guidance provides criteria which types of wetlands covering Natura 2000 habitats and species are qualified under the WFD, which are habitats directly depending on the status of water (Table 8 in the cited document). In the same chapter taking account of these types of wetlands is requested as an essential part of river basin management plans (RBMP). Basic advice for dealing with spatially overlapping aims of the WFD and of Natura 2000 wetlands are given. It is stated, that "the most stringent objective will apply". Furthermore the importance of RBMPs for improving the ecological coherence of the Natura 2000 network is highlighted. Rivers with their banks are named as essential structures as well as ponds functioning as stepping stones (cf. Art. $10 \mathrm{HD}$ ). 
On the basis of experiences and case studies from the first phase of implementation the overall conclusions of a workshop report (EC DG-Env 2010b, p. 12) cover a series of positive findings. In the workshop apparent conflicts could be identified at a local level only. According to the authors of the report those conflicts were caused, in part, by misunderstandings.

While ensuring the proper application of Article 4 para 7 of WFD, noting the particular requirements related to Natura 2000 and other protected areas is an essential need for the future that should finally lead to a more integrated "... work with nature ..." and resulting opportunities could be realised in a "... win-win-win ..." situation. This accentuation made by the authors of the workshop report (EC DG-Env 2010b, p. 6) addresses chances offered by sustainable floodplain management as a tool which integrates navigation, flood protection and adapted agricultural land use, as well as the possible protection of habitats.

The workshop report is completed by a background document which introduces several case studies (EC DG-Env 2010a). On the basis of more than 20 examples for e.g. "differences and commonalities in objectives and scope of the WFD and BHD" and the "coordination of measures in the context of integrated planning to achieve the WFD and BHD objectives" possible actions are illustrated.

In the final conclusion for dealing with incompatibilities of goals of these Directives aiming at the same aquatic ecosystems one finds the following advice (EC DG-Env 2011).

As many HD Annex I habitats are aquatic areas or water-dependent systems, the measures proposed under BD, HD and WFD may be partly the same. As far as water bodies in water-dependent protected areas are concerned, measures under these directives need to be coordinated between the responsible authorities for nature conservation and water management, and included in the WFD programme of measures. It is advisable to start dialogue on the programme of measures of WFD at an early stage in order to avoid conflicts that could arise from misconceptions of the objectives of WFD and BD or HD. Regarding the Danube National Park area that covers the river and the floodplains east of Vienna this coordination is implemented on a broad scale (see Sect. 2.2.3). Regarding the National RBMP these issues are not covered in detail, as strategic and operational structures already exist between public, planning and the responsible legal bodies.

On the other hand, aquatic habitats in active river floodplains with moderate to low connectivity with the main river channel are a rare ecosystem type throughout Europe where rivers have been regulated for navigation and/or flood protection purposes. Many of these water bodies bear high conservational value but often they are not part of protected areas under HD regulation. Therefore, no legal conflict exists when assigning priority to WFD goals in all such situations as an a priori. Even when not-yet - protected by HD, a dialogue on the programme of measures as part of WFD implementation should be a firm request in order to save ecological highlights.

Furthermore, the guidance document (EC DG-Env 2011, p. 9) provides a lot of detailed and instructive knowledge, offering ecological criteria for the identification of water-dependent Natura 2000 sites. The same document states that the “... WFD 
does not change what Member States must achieve for the BHD, but it provides a joint framework for the implementation of measures needed by both WFD and BHD in water dependent Natura 2000 sites ..." (ibid, p. 9). According to this aim it is summarized that the "... WFD in itself does not allow derogating from the requirements set under the BHD, and vice versa ...". Everything planned and decided under the WFD "... must take account of the possible impact on the objectives of the BHD, and vice versa." (ibid, p. 25).

In addition it is explained that "the objectives in the WFD and the BHD are not defined in the same way. In the BHD the overall objectives refer to species and habitat types at the level of the biogeographical region, but also objectives are set on site level to achieve those, whereas the objectives of the WFD refer to water bodies. The objectives for a given water body resulting from the WFD and the Habitats and birds directives have to be aligned in order to assess which measures must be taken" (ibid, p. 11). Generally, the restoration towards good ecological status according to WFD prevails. But there can be exceptions to this general rule "when it would become impossible to maintain a species or habitat type of community interest at a favourable conservation status or, where necessary, to restore such a status". It is important to note that each case has to be decided individually and that it is "advisable to have a clear track record of how judgements are made and what were the considerations made that led to this judgement" (ibid, p. 11). The favourable conservation status of species and habitats is assessed referring to biogeographical regions and not to the site-level. In the workshop report it is recommended to use the water body type and its characteristics as a basis for joint objectives for overlapping water bodies and Natura 2000 sites (ibid, p. 11).

Finally this guidance document highlights the importance of coordination and consultation between the different stakeholders affected by the implementation of BHD and WFD (EC DG-Env 2011, p. 22) and it recommends joint monitoring activities in order to save resources also in a trans boundary context (ibid, p. 26). All in all this paper about frequently asked questions is indeed a very useful guidance document which is practice-oriented and illustrated by several particular cases and practical experiences.

\subsection{Experiences in the Implementation of WFD in Natura 2000 Sites and Recommendations}

\subsubsection{River Basin Management Planning in Austria}

Member States of the EU are required to develop river basin management plans (RMBP) and programmes of measures. The first RMBP had to be delivered in 2009, whereas the programmes of measures developed thereafter need to cover the elements described in detail in Annex VII of WFD. 
Regarding activities in Natura 2000 sites, the Austrian National RBMP covers the necessary management in a context of supervision, integrated into the more basic obligations under WFD implementation and measures for enhancing water policy, especially for developing regional planning programmes. The best example and the largest regarding area are the activities in the Danube National Park, which cover the river reach between Vienna and Bratislava. In this reach the regulation of the Danube carried out in the late 19th century caused still progressing riverbed incision (long-time average $2 \mathrm{~cm}$ per year; Jäger 2013, Fig. 5.3), which results in groundwater level reduction in the adjacent riparian forest and oxbow ensemble along ca. $60 \mathrm{~km}$ of river course. This phenomenon threatens the hydrological basis of the National Park as well as several aspects of commercial navigation. Stopping or at least substantially reducing this deepening process is the goal of the technical solution sought, which has to be achieved without impounding the river, and without causing detrimental effects to the benthic life in the river bottom. Promising solutions have been worked out so far and a pilot study is in full progress. Special legal and environmental requirements effective for this river reach called for special ways of consulting and clearance, and extensive stakeholder involvement, including NGOs. The needs of integration between HD (comprising the substance of BD, too) and WFD are met by a sensitive step-by-step approach. This procedure links ecological, conservation and technical expertise from universities, as well as a special 'consulting citizens forum', and the relevant units of provincial and federal government (G. Janauer, K. Reiter, I. Korner, 2011, FFH-Lebensraumkartierung. Endbericht, Bauabschnitt 1. Flussbauliches Gesamtprojekt. viadonau und Bundesministerium für Verkehr, Innovation und Technologie (bmvit/Österreich), Unpublished report). The status of the Danube River as the assigned European Transport Corridor VII is also respected and technically integrated in all planning steps. Every single step of executing the present pilot project needs full agreement by governmental bodies responsible for conservation issues, navigation aspects, details of material to be used in the construction of groynes and the re-granulation of the river bottom, etc., as well as clearance by the 'consulting citizens forum'. Following this line, and by cross consulting of the different bodies involved in the decision supporting process finally a consensus is worked out which allows the basic balance between ecological, hydrological, and navigation needs.

Another example is the Austrian/Hungarian cross-border National Park Neusiedler See/Fertö To, where water management under the regulation of the WFD and considering the needs of the HD is an integrated task for the two responsible federal water management organisations, the Austrian Federal Agency for Water Management and the Hungarian North-Transdanubian District Environment and Water Directorate (Pannonhalmi and Rojacz 2012; Pannonhalmi 2013). The process of working out sustainable solutions for lake management was based on many years on fact finding and collection of environmental and hydrological data. This information was analysed and commented during official meetings of experts and governmental representatives assigned to the Austrian/Hungarian Border-Water Commission. Specific requirements of habitats ranging from the shallow lake water body, the extensive reed belt to the soda flats, ponds and wetlands in the closer surroundings and their complex and 
often cross-border interaction had to be integrated. This efficient long-time collaboration and final mutual decision on the essential ecological water level conditions sustains today not only the lake and the National Park cross-border compound, but also the wetlands used by migratory birds in a Europe-wide step-stone ensemble that reaches from Eastern Europe via the Hungarian Balaton lake and the Fertö/Neusiedler See to the Oostvaardersplassen wetland area in the Flevoland Province of The Netherlands (Veen 2012).

Of course the National RBMP for Austria is not restricted to Natura 2000 areas as was the HABIT-CHANGE Project (Rannow et al. 2014). It comprises all river basins and their surface and groundwater objects registered under WFD requirements. Under the umbrella of the Federal Ministry of Agriculture, Forest Management, Environment and Water Management all the nine Provinces of Austria have prepared their contributions to the National RMBP (2014).

\subsubsection{River Basin Management Planning in Germany}

As the research project analysing the 2009 established documents of river basin management planning (see Sect. 2.2.2) has shown, most management plans in Germany contain for the most part only general information about how protection and conservation aims of the protected areas were taken into account at the RBMP and during the definition of management aims, and if they were coordinated with the planning of measures. In Schleswig-Holstein, e.g., all measures according to WFD are coordinated with all affected Natura 2000 areas by the responsible conservation authorities. If they identified any conflicts they strived for solutions which don't stand contrary to the objectives of the Natura 2000 sites. The same applies to measures of nature conservation which are coordinated with the objectives of WFD (LU M-V 2009, p. 118; Hofmann and Schmidt 2012, p. 219).

In the RBMP of the Weser River it is documented that in case of conflicting aims coordination was undertaken between the water management and nature conservation authorities concerned. In the result, a solution was found to either fitting both aims or for deciding which of the aims is prior-ranking. Furthermore, it was considered which synergies of conservation aims and objectives of the RBMP of the Weser can be made accessible by suitable measures. Moreover, the Natura 2000 aims for water dependent ecosystems and aquatic habitats are supported by taking into account the protection and conservation objectives, particularly for hydrophilic species and their habitats in the context of monitoring and of planning of measures as well as by coordination with the conservation authorities (Stratmann et al. 2012b, p. 104).

Altogether, the RBMPs in Germany show that regarding the Natura 2000 sites a cooperation of nature conservation and water management has taken place in all Federal States. However, the intensity might have been very different and is reflected only partly in the formal documents (Hofmann and Schmidt 2012, p. 220). 
Since, in general, details on coordination activities are not documented in the RBMP or in the programmes of measures, it is not comprehensible, whether possible conflicts between Natura 2000 and WFD were already solved during the preparation of the programmes of measures or whether they are rather passed on to the subsequent planning levels. Thus, one can assume that a considerable amount of probably unsolved conflicts of objectives is remaining as part of the RBMPs and programmes of measures.

\subsubsection{Recommendations for the Implementation and Future Management Planning}

A look at the first generation of RBMPs in Germany and Austria has shown that the relationship between WFD and BHD was already considered and coordination between water management and nature conservation has taken place. However, the information given in the plans is not very detailed and provides still room for improvement. To avoid conflicts and to utilize synergies in further implementation and planning, the following recommendations can be given on the basis of hitherto planning experience, especially gained in the above-mentioned project on the analysis of German river basin management planning 2009 (see 2.2.2):

1. Network areas and protected areas for Annex IV species should be included.

Representatives of nature conservation have repeatedly demanded that the list of protected areas according to Art. 6 of the WFD should include network areas according to Art. 10 of the HD and protected areas for Annex IV species according to Art. 12 of the HD, as well as the national categories of protected areas, despite this is not being required by European law. This has not yet occurred in Germany, neither, for instance, in Austria or Poland. The inclusion of such areas would, however, encourage the timely harmonisation of objectives and thus the smooth implementation of both directives. On the part of nature conservation, criteria should therefore be developed according to which a consistent approach and selection of the relevant areas can occur (Stratmann et al. 2012a, p. 307). These areas include those of the national biotope network and various national categories of protected areas, in particular nature conservation areas, national parks, biosphere reserves and landscape conservation areas. Once network elements or protected areas that form these network elements are identified, it is also necessary to decide which objectives related to the hydrological regime are critical for their function and should be integrated into agreements with water management.

2. Implementation of measures in Natura 2000 sites should be closely coordinated and prioritised.

The sensitivity of species included in Annex II of the HD to the types of measures (included in the catalogue compiled by LAWA the German Working Group on water issues of the Federal States and the Federal Government) has been 
investigated and showed that in Germany various forms of sensitivity were expected for $60 \%$ of the 90 species considered. Thus, in addition to very beneficial effects for the development of semi-natural biotopes, there may be conflicts involving, in particular, changes in location, loss of area and changes in the open-land biotopes and habitats of the cultural landscape or secondary biotopes. In both cases it is important to ensure a firm and timely coordination between nature conservation and water management in relation to Natura 2000 at subsequent planning stages. This is particularly so because the highly abstract nature of the spatial locations of measures given in the programmes of measures limits the conclusions that can be drawn from these sources. It is thus impossible at present to determine the extent to which conflicts in objectives have already been resolved or-especially - the extent to which the potential of complimentary objectives has been deliberately exploited. Water management should therefore involve nature conservation as thoroughly and promptly as possible in measures for Natura 2000 sites or measures which influence Natura 2000 sites, and thus ensure compatibility with the conservation objectives of Natura 2000 sites. At the same time it is to be recommended that measures having positive effects from the perspective of both the WFD and the Habitats or birds directives should be prioritised, also in terms of implementation. Lower Saxony, for instance, provides an example of how measures can be prioritised in consideration of Natura 2000 sites. One criterion for prioritizing measures for the improvement of hydromorphology and river continuity was their location within water dependent habitats protected by the HD (Hofmann and Schmidt 2012, p. 219 f.).

3. Further development of management plans for Natura 2000 sites.

In many cases, management plans for the Natura 2000 sites were not completed at the first phase of WFD management planning. This means that the objectives of the protected areas could not be assessed for compatibility. Therefore, HD management plans should be further developed so that they contain conservation objectives in a form appropriate for use by management planning. On the one hand, this would enable the timely consideration of nature conservation issues during WFD implementation. On the other hand, functionally and spatially specific conservation objectives for the Natura 2000 sites can be seen as a further WFD objective (WFD Art. 4 para. 2); thus it is recommended that management plans for the water-dependent Natura 2000 sites should be urgently developed at an appropriate level of specification (Stratmann et al. 2012a, p. 308). In this way groundwater levels and qualities relevant to the protection or development of groundwater-dependent terrestrial ecosystems within the Natura 2000 network can also be stipulated by nature conservation and integrated into WFD implementation. These specific stipulations are also a concrete step towards satisfying the prohibition on deterioration and thus meeting the objectives of the WFD for groundwater bodies on which terrestrial ecosystems depend.

Cooperation of water management and nature conservation in practical implementation: The example of the "Landshuter Modell". 
A good example of cooperation between water management and nature conservation is the practice-oriented "Landshuter Modell", which was developed in Southern Germany (Landshut in Bavaria). The basis of this model was developed within a project for restoration of river banks along the river "Große Laber" started in 1995. The water management administration of Landshut and the Government of Lower Bavaria, division of nature conservation, established a successful cooperation during a longer process of planning and implementation partly together with additional partners (Schacht and Lorenz 2013, p. 1). The model shows concrete startingpoints and defines a method for the future cooperation between the different authorities and stakeholders. This comprises, e.g., coordination of priorities as regards content, financial and personnel capacities and responsibilities before the kick-off of the project as well as the joint preparation of the scope of services for specific planning tasks and the invitation for offers for project implementation. Insofar, it substantiates the current RBMPs regarding the coordinated implementation with nature conservation on the local and regional level. The "Landshuter Modell" integrates the Natura 2000 management planning and the planning tasks according to WFD in one plan for development of the ecological functions of surface waters (Schacht and Lorenz 2013, p. 4 et seq.). Following this model, four so-called "ecological development concepts" ("Ökologische Entwicklungskonzepte", "ÖEK") were established at the Isar, the Danube and the Vils between 2003 and 2013. In contrast to traditional sectoral water plans the "ÖEK" provide area-wide mapping of biotope types and differentiated faunistic and floristic investigations, and thus allow for the requirements of Natura 2000 management planning. Vice versa, they overcome the restrictions of Natura 2000 management planning widening their content and spatial scope with regard to the needs of the WFD. On this basis, planning procedures and approvals for the implementation of the designated measures are easier to coordinate. The "Landshuter Modell" is judged to be a successful model since it has made possible and simplified the often intensive and difficult process of coordination between nature conservation and water management. The early coordination of the cooperating administrations as well as an intensive integration of the public and stakeholders are stressed positively. The experiences made show that extensive cooperation allows for more profound solutions as regards conflicting contents and later on for faster planning processes on subsequent planning levels. Therefore, the approach of the "Landshuter Modell" for planning and cooperation seems suitable to be applied to the implementation of RBMP.

\subsection{Conclusions}

All in all, an analysis of the regulations and the river basin management plans of the first planning phase of the WFD has shown that considerably more synergies than conflicts can be identified between the objectives of the WFD and those of the environmental conservation. Both instruments focus on the ecosystem, on the 
development of rivers as well as on the expansion of the habitat network. Particularly for the indigenous species and habitats synergies are to be expected. Furthermore, the objectives of the WFD and the Natura 2000 Directives serve the purposes of preventive flood protection, climate mitigation and climate adaptation.

If conflicts arise, the WFD does not allow derogating from the requirements set under the BHD in general. Therefore, everything planned and decided under the WFD must take into account the possible impact on the objectives of the BHD, and vice versa. Considering a qualified mutual coordination it is necessary that management plans for water-dependent Natura 2000 sites are developed at an appropriate level of specification. Generally, restoration towards good ecological status according to WFD prevails. But there can be exceptions when it would become impossible to maintain a species or habitat type of community interest at a favourable conservation status or, where necessary, to restore such a status.

Summing up it can be stated that both the HD and the WFD contain appropriate legal instruments and sufficient discretionary leeway to find environmentally sound decisions in the individual case. Water and nature conservation authorities have to cooperate in these decisions to avoid conflicts and justify their decisions carefully. Therefore, firm and timely coordination between water and nature conservation authorities is highly recommended.

Open Access This chapter is distributed under the terms of the Creative Commons Attribution Noncommercial License, which permits any noncommercial use, distribution, and reproduction in any medium, provided the original author(s) and source are credited.

\section{References}

Albrecht J, Schmidt C, Stratmann L, Hofmann M, Posselt S, Wendler W, Roßner D, Wachs A (2012) Die Wasserrahmenrichtlinie aus Sicht des Naturschutzes-Analyse der Bewirtschaftungsplanung 2009. In: Naturschutz und Biologische Vielfalt, vol 120, Bonn—Bad Godesberg, p 346

Becker R, Rebsch S (2006) Wasserrahmenrichtlinie überall-Die Anwendung der Richtlinie in verschiedenen Rechtsbereichen. In: Wassernetz NRW, Handbuch Wasserrahmenrichtlinie Nordrhein-Westfalen, Chapter 3, p 38

Birds Directive (1979) Council Directive 79/409/EEC of 19 November 1979, Convention on the Conservation of European Wildlife and Natural Habitats. In: J Communities L 103, p 27

Birds Directive (2009) Directive 2009/147/EC of the European Parliament and of the Council of 30 November 2009 on the conservation of wild birds (codified version). In: Official J Eur Union L20, p 19

Brunken H, Meyer L (2005) Die Bedeutung der Durchgängigkeit von Auenlebensräumen für die Fischfauna. NNA-Berichte 18(1):105-113

Busse M (2009) Nur auf dem Papier? Die Umsetzung der Wasserrahmenrichtlinie aus Sicht der Umwelt- und Naturschutzverbände, Tagung Naturschutz und Wasserrahmenrichtlinie-wie wächst zusammen, was zusammengehört? Alfred Toepfer Akademie für Naturschutz (NNA) in Zusammenarbeit mit dem Niedersächsischen Landesbetrieb für Wasserwirtschaft, Küsten- und Naturschutz (NLWKN) 22/23 September 2009 Schneverdingen. http://www.nna. niedersachsen.de/servlets/download $? \mathrm{C}=59341103 \& \mathrm{~L}=20$. Accessed 30 June 2013 
Convention on wetlands of international importance especially as waterfowl habitat (1971) Ramsar Convention. http://www.ramsar.org/cda/en/ramsar-documents-texts-convention-on/main/ ramsar/1-31-38\%5E20671_4000_0. Accessed 17 Sep 2013

EC-European Commission (2003a) Common Implementation Strategy for the Water Framework Directive (CIS). Guidance document $\mathrm{N}^{\circ}$. 2. identification of water bodies, $\mathrm{p} 24$

EC-European Commission (2003b) Common Implementation Strategy for the Water Framework Directive (CIS). Guidance document $\mathrm{N}^{\circ}$. 12. The Role of Wetlands in the Water Framework Directive, p 69

EC DG-Env-European Commission, Directorate-General for the Environment (2010a) Workshop: biodiversity and water-links between EU nature and water legislation, case studies. Representation of Northrhine-Westfalia to the EU, 17-18 June 2010, Brussels, p 58

EC DG-Env-European Commission, Directorate-General for the Environment (2010b) Workshop: biodiversity and water-links between EU nature and water legislation, workshop report. Representation of Northrhine-Westfalia to the EU, 17-18 June 2010, Brussels, p 12

EC DG-Env-European Commission, Directorate-General for the Environment (2011) links between the water framework directive and nature directives - frequently asked questions, Brussels, p 29

Friedrich G (2003) Wasserrahmenrichtlinie und Naturschutz. In: Grüne Liga e.V. (ed) Die EGWasserrahmenrichtlinie, vol 1, Bewertungsmethoden, Naturschutz, Hochwasserschutz, Revitalisierung von Flussläufen, Berlin, p 39-40

Fuchs M, Preis S, Wirth V, Binzenhöfer B, Pröbstl U, Pohl G, Muhar S, Jungwirth M (2010) Wasserrahmenrichtlinie und Natura 2000, Gemeinsame Umsetzung in Deutschland und Öster-reich am Beispiel der Grenzflüsse Salzach und Inn. In: Naturschutz und Biologische Vielfalt, vol 85, Bonn-Bad Godesberg, p 318

Gopal B (ed) (2013) Environmental flows: An introduction for water resources managers. National Institute of Ecology, Delhi, India, p 248

Habitats Directive (1992) Council Directive 92/43/EEC of 21 May 1992 on the conservation of natural habitats and of wild fauna and flora. In: J Communities L 43, p 66

Hofmann M, Schmidt C (2012) Vertiefende Analyse ausgewählter Schnittstellen, Natura 2000. In: Albrecht J, Schmidt C, Stratmann L, Hofmann M, Posselt S, Wendler W, Roßner D, Wachs A (2012) Die Wasserrahmenrichtlinie aus Sicht des Naturschutzes-Analyse der Bewirtschaftungsplanung 2009. In: Naturschutz und Biologische Vielfalt, vol 120, Bonn—Bad Godesberg, p 193-223

Jäger B (2013) River floodplain habitats and theri aquatic macrophyte vegetation: biodiversity and conservation status defined by connectivity. Diploma thesis, Vienna

Kastens B (2003) Die Wasserrahmenrichtlinie - neue Chancen durch horizontale Interaktion von Wasserwirtschaft und Naturschutz. In: Moss T (ed) Das Flussgebiet als Handlungsraum. Institutionenwandel durch die EU-Wasserrahmenrichtlinie aus raumwissenschaftlichen Perspektiven. Münster, p 289-319

Köhler R (2003) Wasserrahmenrichtlinie und Naturschutz. Ziele, Schnittstellen und Defizite. In: Naturschutz und Landschaftspflege in Brandenburg 12/3, p 101-106

Korn N, Jessel B, Hasch B, Mühlighaus R (2005) Flussauen und Wasserrahmenrichtlinie, Bedeutung der Flussauen für die Umsetzung der europäischen Wasserrahmenrichtlinie. In: Naturschutz und Biologische Vielfalt, vol 27, Bonn-Bad Godesberg, p 258

Krug A, Ehlert T (2003) Auenschutz und Hochwasservorsorge durch die Wasserrahmenrichtlinie. In: Grüne Liga e.V. (ed) Die EG-Wasserrahmenrichtlinie, vol 1, Bewertungsmethoden, Naturschutz, Hochwasserschutz, Revitalisierung von Flussläufen, Berlin, p 56-57

Louis H-W (2000) Bundesnaturschutzgesetz, Kommentar, 1. Teil, $\S § 1$ bis 19, 2. Auflage, Braunschweig

LU M-V-Ministerium für Landwirtschaft, Umwelt und Verbraucherschutz des Landes Mecklenburg-Vorpommern, MLUR-Ministerium für Landwirtschaft, Umwelt und Ländliche Räume des Landes Schleswig-Holstein (2009) Maßnahmenprogramm (gem. Art. 11 EG-WRRL bzw. $\S 36 \mathrm{WHG})$ der Flussgebietseinheit Schlei/Trave 
Möckel S (2007) Umsetzung der Wasserrahmenrichtlinie bei FFH- und Vogelschutzgebieten. Natur und Recht 29:602-608

National RMBP (2014) NGP-Nationaler Gewässerbewirtschaftungsplan Österreich. WEB-Reference: http://www.bmlfuw.gv.at/wasser/wasser-oesterreich/plan_gewaesser_ngp/nationaler_ gewaesserbewirtschaftungsplan-nlp.html

Pannonhalmi M, Rojacz H (2012) Wasserwirtschaft im Grenzbereich Österreich-Ungarn. In: Kárpáti L, Fally J (eds) Fertö-Hanság-Neusiedler See-Seewinkel National Park. Monograph, Szaktudás kiadó Ház, Budapest, p 16

Pannonhalmi M (2013) Hungarian-Austrian Water Commission on the example of the cross border lake Fertö to/Neusiedler See, North-Transdanubian Water Directorate, Györ, p 4

Rannow S, Macgregor NA, Albrecht J, Crick HQP, Förster M, Heiland S, Janauer G, Morecroft MD, Neubert M, Sarbu A, Sienkiewicz J (2014) Managing protected areas under climate change: challenges and priorities. Environmental management. doi: 10.1007/s00267-014-0271-5

Schacht H, Lorenz W (2013) Das „Landshuter Modell“, Ökologische Entwicklungskonzepte mit integrierten Gewässerentwicklungskonzepten und FFH-Managementplänen. In: Auenmaga-zin 4/2013, 4-9. http://www.auenzentrum-neuburg-ingol-stadt.de/Auenzentrum/uploads/ media/ Auenmagazin_04_2013_online.pdf. Accessed 30 June 2013

Schäfer T (2004) Der Schutz von Feuchtgebieten und grundwasserabhängigen Ökosystemen nach der Wasserrahmenrichtlinie. In: Grüne Liga e.V. (ed) Die EG-Wasserrahmenrichtlinie, vol 2, Grundwasser, prioritäre Stoffe, Umsetzung der Wasserrahmenrichtlinie in den Flusseinzugsgebieten, Öffentlichkeitsbeteiligung, Berlin, p 8-10

Schönauer S (2007) Wasserrahmenrichtlinie und Naturschutz-getrennte Aufgaben, gemeinsames Handeln. NNA-Berichte 20(1):82-88

Stratmann L, Hofmann M, Posselt S, Wendler W, Schmidt C, Albrecht J (2012a) Zusammenfassung der Kernempfehlungen. In: Albrecht J, Schmidt C, Stratmann L, Hofmann M, Posselt S, Wendler W, Roßner D, Wachs A (2012) Die Wasserrahmenrichtlinie aus Sicht des Naturschutzes-Analyse der Bewirtschaftungsplanung 2009. In: Naturschutz und Biologische Vielfalt, vol 120, Bonn-Bad Godesberg, p 304-316

Stratmann L, Wendler W, Posselt S, Albrecht J (2012b) Vergleichende Auswertung der Bewirtschaftungspläne. In: Albrecht J, Schmidt C, Stratmann L, Hofmann M, Posselt S, Wendler W, Roßner D, Wachs A (2012) Die Wasserrahmenrichtlinie aus Sicht des Naturschutzes-Analyse der Bewirtschaftungsplanung 2009. In: Naturschutz und Biologische Vielfalt, vol 120, Bonn -Bad Godesberg, p 86-119

Trouwborst A (2011) Conserving european biodiversity in a changing climate: the Bern convention, the European Birds and habitats directives and the adaptation of nature to climate change. Rev Eur Community Int Environ Law 20(1):62-77

Unnerstall H (2003) Der Schutz von Auen nach der EU-Wasserrahmenrichtlinie und dem Bundesnaturschutzgesetz - ein Vergleich. In: Natur und Recht, p 667-677

Veen A (2012) Personal communication, Rijkswaterstaat water framework directive (2000) Directive 2000/60/EC of the European Parliament and of the Council of 23 October 2000 establishing a framework for community action in the field of water policy. In: J Eur Communities L 327, p 72

Wendler W, Albrecht J (2012) Ziele von Wasserrahmenrichtlinie und Naturschutz. In: Albrecht J, Schmidt C, Stratmann L, Hofmann M, Posselt S, Wendler W, Roßner D, Wachs A (2012) Die Wasserrahmenrichtlinie aus Sicht des Naturschutzes-Analyse der Bewirtschaftungsplanung 2009. In: Naturschutz und Biologische Vielfalt, vol 120, Bonn-Bad Godesberg, p 23-44

Wirth V, Preis S, Muhar S, Jungwirth M, Pröbstl U (2000) Umsetzung von WRRL und Natura 2000 am Beispiel der Grenzgewässer Salzach und Inn. In: Natur und Landschaft 87, vol 4, p $156-160$ 